\title{
Pertumbuhan Anak Itik Magelang (Anas javanica) Pasca Tetas dari Induk yang Disuplementasi Kurkumin (Curcuma Longa L.) serta Dipajan Cahaya Putih dan Merah
}

\section{Growth of Magelang Ducks (Anas javanica) Post-hatched from Main Ducks by Curcumin Supplementation (Curcuma Longa L.) with White and Red Light Exposure}

\author{
Luthfiana Ulil Albab $^{1 *}$, Sri Isdadiyanto ${ }^{2}$, Muhammad Anwar Djaelani ${ }^{2}$ \\ ${ }^{1}$ Mahasiswa Departemen Biologi, Fakultas Sains dan Matematika, Universitas Diponegoro \\ ${ }^{2}$ Departemen Biologi, Fakultas Sains dan Matematika, Universitas Diponegoro \\ Jl. Prof. Soedarto, SH, Tembalang, Semarang \\ "Email: luthfianaulilalbab@gmail.com
}

Diterima 31Juli 2018 / Disetujui 25 September 2018

\begin{abstract}
ABSTRAK
Itik magelang merupakan itik lokal yang memiliki prosentase produksi telur mencapai $80 \%$ pada pemeliharaan intensif, untuk meningkatkan produksi telur maka pada penelitian ini itik magelang diberi suplementasi kurkumin serta pajanan cahaya putih dan merah. Penelitian ini bertujuan untuk mengkaji pengaruh pemberian kurkumin serta cahaya putih dan merah pada induk terhadap pertumbuhan anak itik magelang. Rancangan penelitian yang digunakan adalah Rancangan Acak Lengkap (RAL) yang berasal dari 4 induk yang berbeda, yaitu induk A0B0 (kurkumin $0 \mathrm{mg}$ dan cahaya putih), A0B1 (kurkumin $0 \mathrm{mg}$ dan cahaya merah), A1B0 (kurkumin $18 \mathrm{mg}$ dan cahaya putih) dan A1B1 (kurkumin $18 \mathrm{mg}$ dan cahaya merah). Masing-masing kelompok induk diambil 5 anak itik betina untuk diukur morfometrinya. Variabel yang diamati berupa morfometri yang terdiri dari pengukuran panjang badan, panjang sayap, dan panjang kaki. Data yang diperoleh dianalisis menggunakan uji non parametrik Kruskal Wallis dan diuji lanjut menggunakan uji Mann Whitney-U. Hasil penelitian ini menunjukkan bahwa suplementasi kurkumin dan pajanan cahaya putih serta merah pada induk secara umum dapat mempengaruhi pertumbuhan anak itik magelang.
\end{abstract}

Kata kunci: pertumbuhan, itik magelang, morfometri, kurkumin, cahaya merah dan putih.

\begin{abstract}
Magelang duck was a local duck which has egg production up to $80 \%$ with intensive breeding, several ways to increase egg production were curcumin supplementation with red and white light exposure. This research aims to study the effect of curcumin supplementation with red and white light exposure to the growth of magelang ducks. The research design used completely randomized design from 4 differents group of ducks, they were A0B0 (curcumin $0 \mathrm{mg}$ and white light), A0B1 (curcumin $0 \mathrm{mg}$ and red light), A1B0 (curcumin $18 \mathrm{mg}$ and white light) and A1B1 (curcumin $18 \mathrm{mg}$ and red light). Five female ducks were taken from each group and their morphometry were measured. The variables of this research was morphometry that consists of body length, wing length, and feet length. Collected data were analized with Kruskal Wallis non parametric test and further tested with Mann Whitney-U test. The result of this research showed that curcumin supplementation with red and white light exposure to main ducks affected magelang ducks growth.
\end{abstract}

Keywords : growth, magelang ducks, morphometry, curcumin, red and white light.

\section{PENDAHULUAN}

Pemanfaatan itik sebagai penghasil telur maupun daging memerlukan bibit yang berproduksi telur tinggi untuk memperbanyak populasi. Saat ini kemampuan produksi telur pada itik lokal masih beragam, sehingga sifat produksi telur selalu dijadikan sebagai kriteria seleksi ketika dilakukan pemilihan bibit itik unggul (Susanti dkk., 2012). Ciri khas itik magelang adalah adanya warna putih melingkar seperti kalung pada lehernya, sehingga disebut "itik kalung". Itik 
magelang berasal dari daerah Magelang, Jawa Tengah. Wilayah pengembangan itik selain di Kabupaten Magelang, antara lain di Kabupaten Purworejo, Semarang dan Temanggung. Keunggulan itik magelang yaitu memiliki prosentase produksi telur berkisar $48-70 \%$, dengan pemeliharaan intensif produksi telur dapat mencapai $80 \%$. Itik jantan dan betina yang telah diafkir dapat dimanfaatkan sebagai sumber daging, yaitu menjadi itik potong (Dinas Peternakan dan Kesehatan Hewan, 2013).

Kunyit mengandung kurkumin yang dapat merangsang dinding kantong empedu untuk mengeluarkan cairan empedu dan minyak atsiri yang berfungsi mengatur keluarnya asam lambung agar tidak berlebihan sehingga membantu kerja usus (Erniasih dan Saraswati, 2006). Laporan penelitian Strojny et al. (2016) menunjukan bahwa pemberian kurkumin dalam bentuk diamond nanoparticles (DN) pada ayam broiler dapat mempengaruhi perkembangan embrio serta mencegah perkembangan sel kanker in vitro.

Penambahan cahaya pada unggas merupakan salah satu usaha dalam perbaikan pengelolaan budidaya. Cahaya juga merupakan salah satu faktor luar dalam pertumbuhan Aves yang secara langsung berperan dalam mengendalikan berbagai proses fisiologis (Sudjarwo, 2000). Hasil penelitian Liu et al. (2015) menunjukkan bahwa ayam yang diberi pajanan cahaya monokromatik artifisial dapat mengaktifkan Hypothalamic pituitary gonadal (HPG) serta meningkatkan produksi estrogen dan progesteron sehingga meningkatkan produksi telur.

Pertumbuhan dan perkembangan makhluk hidup merupakan hasil interaksi antara faktor internal dan faktor eksternal. Faktor internal, yaitu gen dan hormon, sedangkan faktor eksternal pertumbuhan dan perkembangan adalah pakan dan lingkungannya (Isnaeni, 2006). Berdasarkan hasil penelitian terdahulu, maka penelitian ini bertujuan untuk mengetahui pengaruh suplementasi kurkumin dan pajanan cahaya merah serta putih pada induk terhadap pertumbuhan anak itik magelang.

\section{METODE PENELITIAN}

Penelitian ini dilakukan di Balai Pembibitan dan Budidaya Ternak Non Ruminansia (BPBTNR) Banyubiru, Ambarawa. Anak itik magelang yang digunakan pada penelitian ini sebanyak 20 ekor yang dibagi menjadi 4 kelompok (setiap kelompok terdiri atas 5 itik betina). Anak itik berasal dari induk berumur 42 minggu yang disuplementasi kurkumin sebanyak $18 \mathrm{mg}$ serta dipajan cahaya putih dan merah. Proses pemajanan cahaya berlangsung selama 5 jam setiap harinya mulai dari pukul 18.00-23.00 WIB menggunakan lampu LED dengan besaran cahaya 10 lux. Kurkumin yang digunakan untuk suplementasi induk berasal dari Plamed Green Science Ltd.

Penelitian dilakukan dengan mengoleksi telur dari induk yang dipajan cahaya dan disuplementasi kurkumin. Telur yang telah dikumpulkan dicuci menggunakan desinfektan kemudian dikeringkan. Telur itik dimasukkan ke dalam mesin tetas untuk diinkubasi sampai menetas selama kurang lebih 28 hari. Anak itik yang telah menetas dibedakan jenis kelamin antara itik betina dan jantan. Anak itik magelang diukur morfometrinya, meliputi panjang badan, panjang paruh, dan panjang kaki. Pengukuran morfometri diulang sampai minggu ke-8 penelitian.

Rancangan penelitian menggunakan Rancangn Acak Lengkap (RAL) yang berasal dari 4 induk yang berbeda, yaitu induk A0B0 tidak diberi kurkumin dan dipajan cahaya putih, induk A0B1 tidak diberi kurkumin dan dipajan cahaya merah, induk A1B0 diberi kurkumin dosis 18 mg/ekor/hari dan cahaya putih, serta A1B1 diberi kurkumin sebesar $18 \mathrm{mg} / \mathrm{ekor} / \mathrm{hari}$ dan cahaya merah. Data yang didapat diuji pola distribusi dan homogenitasnya. Data yang diperoleh bersifat homogen namun berdistribusi tidak normal, sehingga dilakukan uji non parametrik Kruskal Wallis untuk mengetahui perbedaan antar kelompok perlakuan kemudian dilakukan uji lanjut menggunakan Mann-Whitney U. Semua analisis dilakukan dengan taraf signifikansi 5\% $(\alpha=0.05)$ (Santoso, 2001). Data dianalisis menggunakan program komputer SPSS 23. 


\section{HASIL DAN PEMBAHASAN}

Pengambilan data pertumbuhan anak itik magelang dimulai dari setelah menetas sampai berumur 7 minggu. Data yang diperoleh disajikan dalam Tabel 1-3 dimana setiap tabel terdapat variabel yang diamati. Panjang badan pada kelompok A0B0, A0B1, A1B0 dan A1B1 tidak berbeda nyata pada minggu pertama, kedua, ketiga, keempat, keenam, ketujuh dan kedelapan ( $P>0,05)$, sedangkan pada minggu kelima terdapat perbedaan nyata $(\mathrm{P}<0,05)$. Hal ini disebabkan pada minggu kelima anak itik masih dalam masa pertumbuhan starter, pada masa pertumbuhan starter pertumbuhan berlangsung dengan cepat sehingga perbedaan pertumbuhan antar kelompok perlakuan dapat terlihat, menurut Rizkuna dkk. (2014) menyatakan bahwa Ca pada itik sebagian besar dideposisikan pada tulang terutama terjadi pada masa starter yaitu dimana saat itik baru memulai pertumbuhan. Indikator pertumbuhan itik bisa dilihat dari pertumbuhan tulangnya. Pertumbuhan tulang akan optimal apabila bahan penyusun tulangnya terpenuhi, terutama mineral Ca, sedangkan Fuller (2004) menyatakan bahwa pertumbuhan jaringan dimulai dari pertumbuhan tulang, otot, dan terakhir lemak. Sampurna dan Suatha (2010) menyatakan bahwa tulang dan kaki berkembang paling dini yang kemudian disusul oleh panjang tubuh dan otot, sedangkan lemak tumbuh paling lambat. Hal ini disebabkan pertumbuhan dan perkembangan tubuh dimulai dari bagian depan (kepala) bergerak ke bagian belakang tubuh dan bagian tubuh yang lain mulai dari ujung kaki menyebar ke atas. Kedua pertumbuhan ini bertemu pada bagian tengah tubuh yang disebut dengan pertumbuhan anteriorposterior dan centripetal.

Kurkumin yang diberikan pada induk A1B0 dan A1B1 dapat memperlancar metabolisme sehingga pertambahan panjang badan dapat berlangsung optimal. Agustina (2006) menyatakan bahwa minyak atsiri dan kurkumin berperan meningkatkan kerja organ pencernaan, merangsang dinding empedu, mengeluarkan cairan empedu dan merangsang keluarnya getah pankreas untuk meningkatkan pencernaan karbohidrat, lemak dan protein. Efek tersebut mengakibatkan adanya peningkatan konsumsi pakan, sehingga kebutuhan protein, karbohidrat dan lemak yang digunakan untuk perkembangan dan pertumbuhan akan terpenuhi. Cahaya merah yang dipajan pada induk A0B1 dan A1B1 dapat meningkatkan pertumbuhan panjang badan karena terdapat peningkatan gerak tubuh. Senaratna et al. (2015) menyatakan bahwa burung yang terpapar cahaya merah dan putih lebih aktif dalam gerakan berjalan, berdiri, minum, agresi, dan peregangan sayap meningkat. Gerakan yang meningkat dapat memperbaiki perkembangan tulang dan mencegah lesi kulit pada hocks, kaki dan dada yang disebabkan oleh istirahat terlalu lama.

Tabel 1. Rata-rata panjang badan pada anak itik magelang.

\begin{tabular}{lcccc}
\hline & A0B0 & A0B1 & A1B0 & A1B1 \\
\hline Minggu 1 & $7,10^{\mathrm{a}}$ & $7,00^{\mathrm{a}}$ & $6,84^{\mathrm{a}}$ & $6,76^{\mathrm{a}}$ \\
Minggu 2 & $9,00^{\mathrm{a}}$ & $9,04^{\mathrm{a}}$ & $8,00^{\mathrm{a}}$ & $9,00^{\mathrm{a}}$ \\
Minggu 3 & $10,70^{\mathrm{a}}$ & $10,60^{\mathrm{a}}$ & $10,60^{\mathrm{a}}$ & $10,20^{\mathrm{a}}$ \\
Minggu 4 & $11,80^{\mathrm{a}}$ & $11,80^{\mathrm{a}}$ & $11,40^{\mathrm{a}}$ & $12,00^{\mathrm{a}}$ \\
Minggu 5 & $15,20^{\mathrm{a}}$ & $12,30^{\mathrm{b}}$ & $15,60^{\mathrm{a}}$ & $15,40^{\mathrm{a}}$ \\
Minggu 6 & $19,80^{\mathrm{a}}$ & $18,50^{\mathrm{a}}$ & $20,00^{\mathrm{a}}$ & $20,20^{\mathrm{a}}$ \\
Minggu 7 & $20,60^{\mathrm{a}}$ & $21,80^{\mathrm{a}}$ & $21,40^{\mathrm{a}}$ & $21,20^{\mathrm{a}}$ \\
Minggu 8 & $25,60^{\mathrm{a}}$ & $24,20^{\mathrm{a}}$ & $23,60^{\mathrm{a}}$ & $24,20^{\mathrm{a}}$ \\
\hline
\end{tabular}

Keterangan:

Angka yang diikuti dengan superskrip yang sama pada baris yang sama menunjukkan tidak terdapat perbedaan nyata pada taraf signifikansi 5\%. A0B0: induk tidak diberi kurkumin dan dipajan cahaya putih; A0B1: induk tidak diberi kurkumin dan dipajan cahaya merah; A1B0: induk diberi kurkumin 18 mg/ekor/hari dan cahaya putih; A1B1: induk diberi kurkumin $18 \mathrm{mg} / \mathrm{ekor} / \mathrm{hari}$ dan cahaya merah. 
Tabel 2. Rata-rata panjang sayap pada anak itik magelang.

\begin{tabular}{lcccc}
\hline & A0B0 & A0B1 & A1B0 & A1B1 \\
\hline Minggu 1 & $4,10^{\mathrm{a}}$ & $4,00^{\mathrm{a}}$ & $4,00^{\mathrm{a}}$ & $3,90^{\mathrm{a}}$ \\
Minggu 2 & $4,40^{\mathrm{a}}$ & $4,60^{\mathrm{a}}$ & $4,50^{\mathrm{a}}$ & $4,30^{\mathrm{a}}$ \\
Minggu 3 & $5,70^{\mathrm{a}}$ & $5,10^{\mathrm{a}}$ & $5,10^{\mathrm{a}}$ & $5,40^{\mathrm{a}}$ \\
Minggu 4 & $6,00^{\mathrm{a}}$ & $6,20^{\mathrm{a}}$ & $5,80^{\mathrm{a}}$ & $6,20^{\mathrm{a}}$ \\
Minggu 5 & $15,20^{\mathrm{a}}$ & $12,30^{\mathrm{b}}$ & $15,60^{\mathrm{a}}$ & $15,40^{\mathrm{a}}$ \\
Minggu 6 & $19,80^{\mathrm{a}}$ & $18,50^{\mathrm{a}}$ & $20,00^{\mathrm{a}}$ & $20,20^{\mathrm{a}}$ \\
Minggu 7 & $17,80^{\mathrm{a}}$ & $18,20^{\mathrm{a}}$ & $16,60^{\mathrm{a}}$ & $15,40^{\mathrm{a}}$ \\
Minggu 8 & $21,60^{\mathrm{a}}$ & $25,60^{\mathrm{b}}$ & $19,00^{\mathrm{a}}$ & $19,40^{\mathrm{a}}$ \\
\hline
\end{tabular}

Keterangan:

Angka yang diikuti dengan superskrip yang sama pada baris yang sama menunjukkan tidak terdapat perbedaan nyata pada taraf signifikansi 5\%. A0B0: induk tidak diberi kurkumin dan dipajan cahaya putih; A0B1: induk

Panjang sayap kelompok A0B0, A0B1, A1B0 dan A1B1 pada minggu pertama sampai minggu ketujuh menunjukkan bahwa seluruh kelompok perlakuan tidak berbeda nyata $(\mathrm{P}>0,05)$, hal ini disebabkan oleh pertumbuhan sayap yang relatif konstan pada awal pertumbuhan, Ariawan dkk. (2016) menyatakan bahwa bagian dada dan paha berkembang lebih dominan selama pertumbuhan apabila dibandingkan pada bagian sayap dan punggung, sehingga perkembangan sayap dan punggung relatif konstan. Hasil pengukuran minggu kedelapan menunjukkan adanya perbedaan nyata pada kelompok perlakuan A0B0, A0B1, A1B0, dan A1B1 $(\mathrm{P}<0,05)$, hal ini terjadi karena anak itik masih dalam masa pertumbuhan starter, pada masa pertumbuhan starter pertumbuhan berlangsung dengan cepat sehingga perbedaan pertumbuhan antar kelompok perlakuan dapat terlihat, menurut Rizkuna dkk. (2014) menyatakan bahwa Ca pada itik sebagian besar dideposisikan pada tulang terutama terjadi pada masa starter yaitu dimana saat itik baru memulai pertumbuhan. Indikator pertumbuhan itik bisa dilihat dari pertumbuhan tulangnya. Pertumbuhan tulang akan optimal apabila bahan penyusun tulangnya terpenuhi, terutama mineral Ca.

Cahaya merah yang dipajan pada induk A0B1 dan A1B1 dapat meningkatkan pertumbuhan sayap, pertumbuhan sayap tertinggi dicapai oleh anak itik dari induk A0B1 karena cahaya merah dapat meningkatkan kadar kalsium dalam darah. Kasiyati dkk. (2010) menyatakan bahwa unggas yang menerima cahaya merah, hijau dan biru serta kontrol memiliki kadar kalsium darah pada umur 7 dan 9 minggu yang relatif tinggi karena kalsium dalam plasma digunakan untuk pertumbuhan tulang. Kurkumin yang diberikan pada induk A1B0 dan A1B1 dapat mempengaruhi pertumbuhan sayap karena kunyit sebagai sumber kurkumin mengandung protein dan kalsium. Hasil analisis di Laboratorium Balai Penelitian Bioteknologi Tanaman Pangan Bogor, menunjukkan bahwa dalam ampas kunyit mengandung $\mathrm{Ca}(0,12 \%)$, dan protein $(5,524 \%)$ (Balai Penelitian Bioteknologi Tanaman Pangan, 2000).

Pertumbuhan sayap terjadi lebih lambat dari pertumbuhan yang terjadi pada sumbu tubuh, menurut Dewanti dkk. (2013) bagian dada dan bagian paha berkembang lebih dominan selama pertumbuhan apabila dibandingkan pada bagian sayap. Pertumbuhan panjang badan terjadi lebih lambat dari pertumbuhan kaki, hal ini sesuai dengan pendapat Sampurna dan Suatha (2010) yang menyatakan bahwa tulang dan kaki berkembang paling dini yang kemudian disusul oleh panjang tubuh dan otot, sedangkan lemak tumbuh paling lambat. Hal ini disebabkan pertumbuhan dan perkembangan tubuh dimulai dari bagian depan (kepala) bergerak ke bagian belakang tubuh dan bagian tubuh yang lain mulai dari ujung kaki menyebar ke atas.

Panjang kaki pada kelompok A0B0, A0B1, A1B0 dan A1B1 berbeda nyata pada minggu pertama $(\mathrm{P}<0,05)$, sedangkan pada minggu 
kedua sampai kedelapan seluruh kelompok perlakuan menunjukkan tidak terdapat perbedaan nyata $(P>0,05)$. Kunyit sebagai sumber kurkumin yang diberikan pada induk itik A1B0 dan A1B1 mengandung protein dan kalsium yang dibutuhkan untuk pertumbuhan tulang, Hasil penelitian Balai Penelitian Bioteknologi Tanaman Pangan (2000) menunjukkan bahwa kunyit mengandung bahanbahan anorganik seperti $\mathrm{N}(0,884 \%), \mathrm{P}(0,211 \%)$,
$\mathrm{Ca}(0,12 \%)$, dan bahan-bahan organik seperti lemak $(3,61 \%)$, serat kasar $(4,28 \%)$, protein $(5,524 \%)$, abu $(8,03 \%)$ dan air $(15,41 \%)$. Ridla dkk. (2016) menyatakan bahwa senyawa organik utama penyusun tulang adalah protein. Protein utama penyusun tulang adalah kolagen tipe 1 yang merupakan 90-95\% bahan organik utama pada tulang, sedangkan sisanya adalah medium homogen yang disebut substansi dasar.

Tabel 3. Rata-rata panjang kaki pada anak itik magelang.

\begin{tabular}{lcccc}
\hline & A0B0 & A0B1 & A1B0 & A1B1 \\
\hline Minggu 1 & $2,06^{\mathrm{a}}$ & $2,40^{\mathrm{b}}$ & $2,90^{\mathrm{c}}$ & $2,40^{\mathrm{bc}}$ \\
Minggu 2 & $3,06^{\mathrm{a}}$ & $2,80^{\mathrm{a}}$ & $3,24^{\mathrm{a}}$ & $2,96^{\mathrm{a}}$ \\
Minggu 3 & $3,20^{\mathrm{a}}$ & $3,22^{\mathrm{a}}$ & $3,30^{\mathrm{a}}$ & $3,26^{\mathrm{a}}$ \\
Minggu 4 & $3,40^{\mathrm{a}}$ & $3,80^{\mathrm{a}}$ & $3,82^{\mathrm{a}}$ & $3,80^{\mathrm{a}}$ \\
Minggu 5 & $4,62^{\mathrm{a}}$ & $4,12^{\mathrm{a}}$ & $4,44^{\mathrm{a}}$ & $4,30^{\mathrm{a}}$ \\
Minggu 6 & $5,96^{\mathrm{a}}$ & $5,94^{\mathrm{a}}$ & $5,76^{\mathrm{a}}$ & $6,14^{\mathrm{a}}$ \\
Minggu 7 & $6,30^{\mathrm{a}}$ & $6,42^{\mathrm{a}}$ & $6,50^{\mathrm{a}}$ & $6,10^{\mathrm{a}}$ \\
Minggu 8 & $6,64^{\mathrm{a}}$ & $6,46^{\mathrm{a}}$ & $6,70^{\mathrm{a}}$ & $6,90^{\mathrm{a}}$ \\
\hline
\end{tabular}

Keterangan:

Angka yang diikuti dengan superskrip yang sama pada baris yang sama menunjukkan tidak terdapat perbedaan nyata pada taraf signifikansi 5\%. A0B0: induk tidak diberi kurkumin dan dipajan cahaya putih; A0B1: induk tidak diberi kurkumin dan dipajan cahaya merah; A1B0: induk diberi kurkumin 18 mg/ekor/hari dan cahaya putih; A1B1: induk diberi kurkumin $18 \mathrm{mg} / \mathrm{ekor} / \mathrm{hari}$ dan cahaya merah.

Cahaya merah yang dipajan pada induk A0B1 dan A1B1 dapat meningkatkan nafsu makan sehingga pertumbuhan tulang juga meningkat, Sulistyoningsih (2009) menyatakan bahwa cahaya merah meningkatkan aktifitas makan unggas, sehingga pemberian perlakuan dengan cahaya merah dapat mencegah dischondroplasia (kerapuhan tulang). Parry (2011) berpendapat bahwa kelembaban relatif mesin tetas mempengaruhi penyerapan kalsium dari kerabang telur. Kalsium $(\mathrm{Ca})$ berfungsi sebagai pembentuk tulang. Kelembaban relatif yang optimal menjadikan penyerapan kalsium berjalan sempurna, sedangkan menurut Leksrisompong et al. (2007) temperatur berguna untuk mengaktifkan provitamin $\mathrm{D}$, metabolisme kalsium dan phospor. Provitamin D berfungsi untuk menstimulasi sintesis protein yang membawa kalsium. Kelembaban berfungsi sebagai perantara pertukaran panas dalam kerabang, guna mengoptimalkan proses metabolisme kalsium, phospor, dan sintesis protein yang membawa kalsium untuk pembentukan tulang dan kaki embrio, sehingga panjang kaki pada minggu pertama berbeda nyata.

Hasil pengukuran morfometri mulai dari minggu pertama sampai minggu kedelapan menunjukkan bahwa setiap organ tubuh memiliki kecepatan laju pertumbuhan yang berbeda, hal ini sesuai dengan pendapat Sampurna (2013) bahwa setiap organ, jaringan ataupun bagian tubuh pada setiap fase mempunyai kecepatan atau laju pertumbuhan yang berbeda. Umumnya masa percepatan pertumbuhan terjadi sebelum ternak mengalami pubertas (dewasa kelamin) kemudian terjadi proses perlambatan, pertumbuhan memiliki tahap yang cepat dan lambat, tahap cepat terjadi pada saat lahir sampai pubertas, sedangkan tahap lambat terjadi saat kedewasaan tubuh telah tercapai (Agustina dkk, 2013). Bagian tubuh yang berfungsi lebih awal akan berkembang lebih dulu. Hal ini sesuai dengan pendapat Eka dkk. (2014) 
yang menyatakan semua bagian dari tubuh hewan tumbuh dengan cara teratur, namun tidak tumbuh dengan suatu kesatuan karena berbagai jaringan tumbuh dengan laju yang berbeda dari lahir sampai dewasa.

\section{KESIMPULAN}

Suplementasi kurkumin sebesar $18 \mathrm{mg}$ dan pajanan cahaya putih serta merah yang diberikan pada induk itik dapat meningkatkan pertumbuhan badan anak itik magelang.

\section{UCAPAN TERIMAKASIH}

Artikel ini merupakan bagian dari hasil penelitian yang didanai oleh Dr. Kasiyati, M.Si tahun 2015.

\section{DAFTAR PUSTAKA}

Agustina, L. 2006. Penggunaan Ramuan Herbal sebagai Feed Additive untuk Meningkatkan Performans Broiler. Lokakarya Nasional Inovasi Teknologi Dalam Mendukung Usahaternak Unggas Berdayasaing 47-52.

Agustina, D., Iriyanti, N. dan Mugiyono, S. 2013. Pertumbuhan dan Konsumsi Pakan pada Berbagai Jenis Itik Lokal Betina yang Pakannya di Suplementasi Probiotik. Jurnal Ilmiah Peternakan 1(2): 691 - 698.

Ariawan, P. T. B., Siti, N. W. Sukmawati, N. M. S. 2016. Pengaruh Pemberian Ransum Diferentasi dengan Probiotik Berbasis Sari Daun Pepaya terhadap Potongan Karkas Komersial Ayam Kampung. Jurnal Peternakan Tropika. 4(2):351-362.

Balai Penelitian Bioteknologi Tanaman Pangan. 2000. Hasil Analisis Ampas Kunyit. Bogor: Laboratorium Tanah dan Tanaman IPB.

Dewanti, R., Irham, M. dan Sudiyono, 2013. Pengaruh Penggunaan Enceng Gondok (Eichornia crassipes) Terfermentasi dalam Ransum Terhadap Persentase Karkas, Non-Karkas, dan Lemak Abdominal Itik Lokal Jantan Umur Delapan Minggu. Buletin Peternakan Vol. 37(1): 19-25.
Dinas Peternakan dan Kesehatan Hewan. 2013. Potensi Ternak di Jawa Tengah. Dinas Peternakan dan Kesehatan Hewan Provinsi Jawa Tengah.

Eka, Y. Sampurna, I. P. dan Nindhia T. S. 2014. Pertumbuhan Dimensi Lebar Tubuh Pedet Sapi Bali. Indonesia Medicus Veterinus 3(3):230-236.

Erniasih, I. dan Saraswati, T. R. 2006. Penambahan Limbah Padat Kunyit (Curcuma Domestica) pada Ransum Ayam dan Pengaruhnya terhadap Status Darah dan Hepar Ayam (Gallus sp). Buletin Anatomi dan Fisiologi Vol. 14(2):1-6.

Fuller M. F. 2004. The Encyclopedia of Farm Animal Nutrition. Cambridge (US): CABI Publishings

Isnaeni, W. 2006. Fisiologi Hewan. Yogyakarta: Penerbit Kanisius.

Kasiyati, Kusumorini, N., Maheswari, H. Manalu, dan W. 2010. Kajian Fisiologis Status Kalsium Puyuh (Coturnix Coturnix Japonica) setelah Pemberian Cahaya Monokromatik. Buletin Anatomi dan Fisiologi Vol. 18(1):1-11.

Leksrisompong, N., Romero, S. H., Plumstead, W. P., Brannan, E. K. and Brake, J. 2007. Broiler Incubation: Effect of elevated temperature during late incubation on body weight and organs of chicks. Poultry Science 86: 2685--2691.

Liu, L., Li, D., Gilbert, E. R., Xiao, Q., Zhao X., Wang, Y., Yin, H. and Zhu, Q. 2015. Effect of Monochromatic Light on Expression of Estrogen Receptor (ER) and Progesterone Receptor (PR) in Ovarian Follicles of Chicken. Plos One Vol 10:114.

Parry B. Paimin. 2011. Mesin Tetas. Jakarta: Penerbit Swadaya.

Ridla, Riana, A. A., dan Kristanto, H. 2016. Pengaruh Pemberian Ekstrak Kunyit Asam (Curcuma Domestica-Tamarindus Indica) Terhadap Pertumbuhan dan Perkembangan Skeleton Fetus Mencit Balb/C dalam 
Periode Gestasi. Undergraduate Thesis, Diponegoro University.

Rizkuna A., Atmomarsono, U. dan Sunarti, D. 2014. Evaluasi Pertumbuhan Tulang Ayam Kampung Umur 0-6 Minggu dengan Taraf Protein dan Suplementasi Lisin dalam Ransum. JITP vol. 3(3):121-125.

Sampurna, I. P. dan Suatha, I. K. 2010. Pertumbuhan Alometri Dimensi Panjang dan Lingkar Tubuh Sapi Bali Jantan. Jurnal Veteriner Vol. 11(1):46-51.

Sampurna, I. P. 2013. Patterns of Growth Organ and Body Parts Broiler. Tesis. Institut Pertanian Bogor.

Santoso, S. 2001. Statistik Nonparametrik. Jakarta: PT Elex Media Komputindo.

Senaratna, D., samarakone, T. S. dan Gunawardena, W. W. D. A. 2015. Red Color Light at Different Intensities Affects the Performance, Behavioral Activities and Welfare of Broilers. Asian-Australian Journal Animal Science Vol. 29(7):10521059.

Strojny, B., Grodzik, M., Sawosz, E., Winnicka, A., Kurantowicz, N., Jaworski, S., Kutwin, M., Urbanska, K., Hotowy, A., Wierzbicky, M. and Chwalbog, A. 2016. Diamond Nanoparticles Modify Curcumin Activity: In Vitro Studies on Cancer and Normal Cells and In Ovo Studies on Chicken Embryo Model. Plosone Journal 11(10).

Sudjarwo, E. 2000. Upaya Peningkatan Penampilan Melalui Perlakuan Jenis Lampu dan Lama Penambahan Cahaya pada Burung Puyuh. Lembaga Penelitian Universitas Muhammadiyah Malang.

Sulistyoningsih, M. 2009. Pengaruh Pencahayaan (Lighting) Terhadap Performans dan Konsumsi Protein pada Ayam. Prosiding Seminar Nasional UPI Bandung 2009.

Susanti, T. Noor. R. R., Hardjosworo, P. S. dan Prasetyo, L. H. 2012. Relation ship of Molting Trait and Egg Production on
Crossbrad Peking and Alabio Duck. JITV 17(2), 112-119. 